\title{
Neo-Atlantis: The Netherlands under a 5-m sea level rise
}

\author{
Xander Olsthoorn - Peter van der Werff • \\ Laurens M. Bouwer • Dave Huitema
}

Received: 11 August 2005 / Accepted: 26 March 2008 / Published online: 4 June 2008

(C) The Author(s) 2008

\begin{abstract}
What could happen to the Netherlands if, in 2030, the sea level starts to rise and eventually, after 100 years, a sea level of $5 \mathrm{~m}$ above current level would be reached? This question is addressed by studying literature, by interviewing experts in widely differing fields, and by holding an expert workshop on this question. Although most experts believe that geomorphology and current engineering skills would enable the country to largely maintain its territorial integrity, there are reasons to assume that this is not likely to happen. Social processes that precede important political decisions - such as the growth of the belief in the reality of sea level rise and the framing of such decisions in a proper political context (policy window) - evolve slowly. A flood disaster would speed up the decision-making process. The shared opinion of the experts surveyed is that eventually part of the Netherlands would be abandoned.
\end{abstract}

\section{Introduction}

A possible consequence of the ongoing and foreseen change in the climate system is the disintegration of the West-Antarctic Ice Sheet (WAIS). Such an event would lead to a 5-m sea level rise (SLR) according to a recent estimate (Lythe et al. 2001). Consequently, low elevation coastal areas would be threatened. The current global population in these areas is estimated to be 300-400 million and these inhabitants earn approximately 1,500 billion dollars (Nicholls et al. this issue). The present article is about the Netherlands facing such SLR. It reports on a case study which was part of the ATLANTIS project. This project

X. Olsthoorn $(\bowtie) \cdot$ P. van der Werff $\cdot$ L. M. Bouwer $\cdot$ D. Huitema Institute for Environmental Studies, Vrije Universiteit, De Boelelaan 1087, 1081 HV Amsterdam, the Netherlands e-mail: aaolsthoorn@gmail.com

L. M. Bouwer

e-mail: Laurens.bouwer@ivm.vu.nl

D. Huitema

e-mail: Dave.huitema@ivm.vu.nl 
attempted to produce an analysis of the possible socio-economic implications of such SLR and an analysis of the consequences of extreme seal level rise in three European regions.

The ATLANTIS project team chose to limit the study by considering only a single scenario for SLR: the assumption is that sea level would rise by $5 \mathrm{~m}$ in a period of one century, starting in 2030. The choice for 2030 as the starting point emphasises the hypothetical character of our study, while on the other hand it enhances its psychological credibility in that 2030 is within a comprehensible time span of the present. We are aware of the fact that the speed of SLR in this scenario is extremely unlikely from the perspective of current predictions on WAIS disintegration and SLR (see Kasperson et al. this issue; Nicholls et al. this issue; Hansen 2005; Oppenheimer and Alley 2005).

One might ask whether it would be possible to avoid or lessen a disintegration of the WAIS and ensuing SLR. We leave the issue of designing a climate change policy including greenhouse gas emission reductions and adaptation - to others, such as Guillerminet and Tol (this issue). What remains is the 'what if' question about the societal response in the Netherlands if such a SLR does occur.

In the Netherlands, a large SLR and its dangers is not something that is remote and outside the scope of imagination. For instance, in 1991 the Dutch novelist Evert Hartman published a bestselling youth novel, which takes place in the 22nd century after enormous SLR due to climate change. In this story, a large part of the Netherlands is submerged and the former heart of the Netherlands - an area comprising the cities of Amsterdam, Rotterdam and The Hague - has become an island polder, linked to the mainland by tunnels. But even outside the circle of fiction writers, the issue has been taken up (Hartman 1991). In 1986, the Dutch Directorate-General for Public Works and Water Management ('Rijkswaterstaat') performed a study that looked into the possibility of adapting to a 5-m SLR occuring over a period of 200 years (Rijkswaterstaat-DGW 1986). Preservation of the Netherlands in more or less its current shape was deemed technologically possible, but the study also described the possibility of abandoning a major part of the Netherlands.

One can legitimately question the reality of such visioning exercises, whether they are initiated by novelists, government departments, or researchers such as ourselves. Predictions about the state of the world in 2006 that were made in the 1950s have generally been proved to be far from reality and tend to reflect the issues and trends that were deemed relevant in the 1950s. However, in the 'risk society' (Beck 1992) with high levels of uncertainty, there is a need for the build up of adaptive capacity (Gunderson and Holling 2002). An essential ingredient of such capacity will be a continued dialogue on possible futures (Dryzek 1987) and our article should be seen in this light.

The structure of this article is as follows. The next section gives contextual information, i.e. a brief overview of current flood safety in the Netherlands in terms of geography and policy. Section 3 presents the framework that we used to structure our analysis; Section 4 describes our methodology and sources of information; the scenario that we derived from our analysis is presented in Section 5; and finally, Section 6 discusses and concludes.

\section{Context: Flood risk in the Netherlands}

\subsection{Floods and flood protection, historical context}

The physical shape of the Netherlands and the safety from flooding are not exclusively related to SLR. Both the shape of the country and the flood risk are largely man-made, and therefore manageable. The Netherlands are truly 'man-made lowlands' (Van de Ven 1996). 
To Dutch people this view may seem rather obvious, however, we surmise that to most other people it is not. The Netherlands as it is today is the result of centuries of water and flood management practices. Without such, the geographical shape of the Netherlands would be entirely different as about half the country is located below sea-level. This circumstance profoundly influences views on adaptation to SLR, and as a result, opinions regarding policy responses to SLR (e.g. raising dike heights) differ to those in other countries where flood hazards are less prominent. Water is important to current Dutch society and culture. The Dutch are proud of their water management and of the way they have turned water into an endowment. This makes the Dutch different from other people, in their own opinion, but also in the opinion of others (see e.g. Schama 1987). With respect to water management culture, floods are no longer perceived as 'acts-of-god' that are entirely outside human control. The population expects their government to protect them, just as they expect government protection from industrial hazards (Wissink and Bouma 2002; Huysmans and Steenbekkers 2002; De Boer et al. 2003). In relation to this, there is a strong belief in the technological and financial possibilities to control water and guarantee flood safety. The history of the Dutch man-made flood control system dates back to the Middle Ages (Tol and Langen 2000; Kaijser 2002). Until the 19th century, flood protection was a local concern, organised by waterboards that have existed since the 12 th century. It became an issue for the national-level public administration during the French occupation in the 19th century, when the Dutch system of public administration was greatly centralised (Kuks 2004; Tol and Langen 2000; Bressers et al. 1995).

The history of flood risk management is strongly correlated with the occurrence of floods, which have served as 'focussing events' (Birkland 1997) for deciding on flood risk measures. For instance the 1916 flood which even threatened Amsterdam preceded the decision - approved of in 1920 - to construct the barrier dam called the 'Afsluitdijk'. This dam, which was finished in 1930, connects dike ring areas 6 and 12 (see Fig. 1) and prevents the North Sea from entering the former tidal estuary then known as the Zuiderzee (see Huitema 2002, Huitema and Kuks 2004). Actually, the construction of this dam was the first step in a scheme that involved reclamation ("inpoldering") of large parts of the Zuiderzee. This scheme was finished in 1968, with the creation of IJsselmeerpolders (dike ring area 8 in Fig. 1). The origins of the current flood defence system date back to the disastrous storm surge in February 1953, which took the lives of 1,836 people in the Southwestern part of the Netherlands. This disaster prompted the implementation of the so-called Delta Act that stipulated flood safety levels and the means to reach these levels. The dams that close the arms of the estuary in the southwest of the Netherlands - the works were completed in the beginning of the $1980 \mathrm{~s}$ - constitute the exemplary result of this law. Currently, flood protection is regulated under the Flood Defences Act, which was implemented in 1996, after a series of floods and near-floods along the rivers, such as the 1993 event when hundreds of thousands of people in dike-ring areas 41 and 43 were evacuated before water levels of the river Rhine peaked to dangerous levels.

Over the past centuries and up until the last half of the 20th century, flood safety policy making extended beyond guarding territorial integrity and included the reclamation of new land ('inpoldering'). Today, this association has gone. Reclamation at a large scale is not part of current thinking, and measures to obtain flood safety may now even include a certain loss of territorial integrity. For instance, the creation of excess water storage capacity along rivers in order to obtain flood safety down stream implies that such areas would become uninhabitable. Flood management has shifted away from building ever higher and massive dikes to contain water. This change in approach is closely related to the rise in the value of ecology and nature in the public mind. The exemplary impact of this shift on flood 


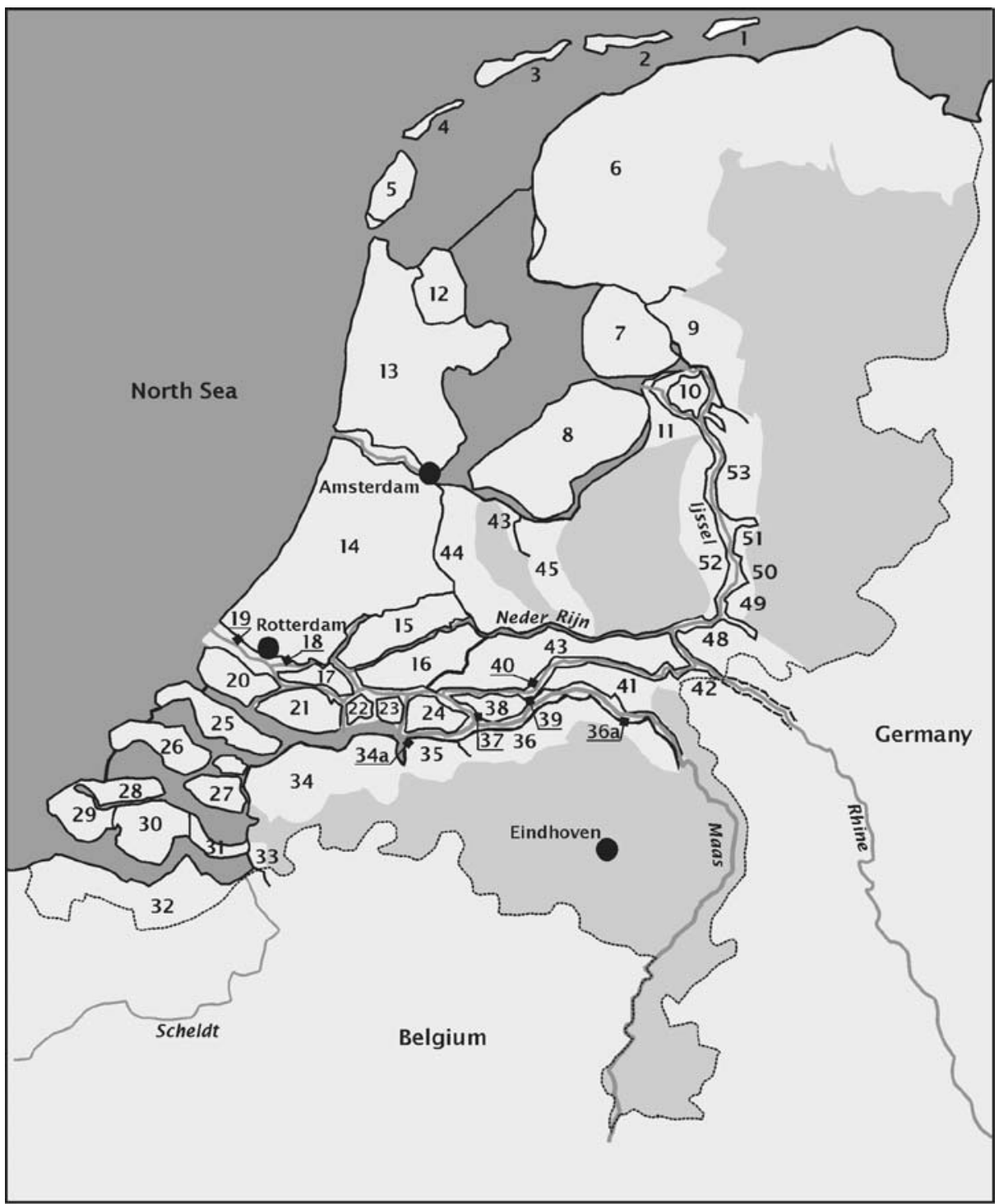

Dike or dune

High grounds, not at risk to flood

34 Number of dike ring area

Fig. 1 Distribution of flood risks across the Netherlands

safety policy has been the decision close off the Eastern Scheldt Estuary - deemed necessary after the 1953 flood disaster - by a moveable dam instead of a closed dam. The moveable dam closes only when water levels reach dangerous heights. In this way the natural tidal variation in water level and associated ecosystems are preserved.

Today, in the institutions that are engaged in flood policy development new approaches are being developed. These developments are prompted by considering the impacts of traditional flood safety approaches on the environment, landscape and cultural heritage and the notion that climate change would imply higher probabilities of greater river discharges 
(Van der Grijp et al. 2006). Expected SLR (of limited magnitude) is another concern that has encouraged rethinking of flood control policy. The new approach - laid out in the Fourth National Water Policy Plan of 1998 - would have serious implications for strategic land use planning in the Netherlands. For instance, a direct implication is that some (lowlying) areas must be designated to serve as excess water storage basins in case of extreme high river discharges. Decision-making involves the consideration and trading-off of impacts with respect to different endpoints (see for instance Brouwer and Van Ek 2004). So-called integrated assessment of the various pros and cons of policies involves stakeholder consultation in order to identify what is considered to be important.

\subsection{Safety standards}

Figure 1 represents areas in the Netherlands that are at risk to river flood or sea surge (light coloured areas). These areas at risk are divided into so-called dike-ring areas ${ }^{1}$. A dike-ring area is a legal concept - laid out in the Flood Defences Act - that refers to a region for which a maximum acceptable flood return period (or flood probability) is established. Flood safety management authorities must pursue these safety levels. The boundaries of the dike-ring areas are constituted by flood defence structures. These defence structures encompass dikes and natural coastal boundaries (e.g. dunes) as well as sluices and other structures that are part of water management systems.

The concept of statutory flood safety standards that must be guaranteed by public administrative bodies dates back to the Delta Act. Current safety standards have their origin in early political decisions that were based on historical probabilities of extreme water levels and cost-benefit analysis of flood defences policies (Van Dantzig 1956; see also Eijgenraam 2006). These decisions took account of the variation of the assets-at-risk across the Netherlands (Ten Brinke and Bannink 2004). Dike-ring areas 13 and 14 - which comprise the larger Dutch cities and major industrial areas - have been endowed with the highest protection levels and are protected by dikes and other structures that are designed to withstand water levels associated with floods that would occur with a probability of once in 10,000 years. The less populated areas in the Southwest and in the North of the Netherlands are protected to once in 4,000-year event levels. Along the rivers (e.g. dike ring areas 40, 41 and 43), flood probability is highest, at once in 1,250 years. Flood safety standards for the series of areas along the river Meuse (the dike-ring areas are not shown in Fig. 1) have been set at a flood probability of once in 250 years.

Whether or not these standards are met is assessed by considering two explanatory variables that determine flood probability. The first is the assumed probability of high-water levels that would result in overtopping of dikes (overtopping rate). The second factor relates to assumptions on the integrity-failure probabilities of the water defence structures. One may tend to think that overtopping of dikes is the main cause of flooding. In fact most floods occur due to dike breaches before dikes are overtopped, which can be caused by processes such as sliding of the inner or outer dike slope, erosion of the dike revetment, and 'piping', which causes water to flow under the dike and to erode the dike body (TAW 2000). For instance, in the hot and dry summer of 2003 a small local flood occurred near Amsterdam when a centuries old dike made of peat failed due to desiccation. This was a real 'surprise' as nobody had thought of this mechanism leading to failure.

\footnotetext{
${ }^{1}$ Figure 1 does not show the 50 dike-ring areas along the river Meuse as these are all very small in comparison with the dike-ring areas shown on the map.
} 
The 1996 Flood Defences Act stipulates decadal evaluation of safety standards. This evaluation now includes the assessment of other failure mechanisms in addition to overtopping. The first assessment of dike safety (Rijkswaterstaat-DWW 2003) found that about $50 \%$ of all $3,558 \mathrm{~km}$ of primary flood defence structures in the Netherlands met statutory requirements. Research to better assess flood risks is ongoing (RijkswaterstaatDWW 2005; Rijkswaterstaat-DWW 2006). This research aims at assessing probabilities of failures of the flood defences as well as the assessment of the impacts of floods in terms of casualties and economic damage. Results should inform decision making with respect to trading off costs (including non-monetary costs) of flood-control measures and associated avoided impacts (see also Bouwer and Vellinga, 2007).

\subsection{Costs and benefits associated with flood protection}

Table 1 presents an economic assessment of the current flood risk policy to cope with climate change (i.e. expected changing river discharge patterns) and expected SLR. This SLR - about $0.8 \mathrm{~m}$ in 100 years - is the result of a global SLR and a local tectonic subsidence of the Western part of the Netherlands. This table - based on Stolwijk and Verrips (2000) - shows economic assessments of five major plans, of which the first three relate to flood safety in the upper Rhine area, and the others to flood safety in the Western part of the Netherlands (where potential damage is orders of magnitude larger). They concluded that the total annual costs (loss of welfare) of protection against foreseen climate change and SLR, are in the order of magnitude of $€ 600$ million, while the benefits (avoided annualised damage) exceed the costs by a factor of about 5 . Note that the Dutch Gross National Product (GDP) in 2000 was about $€ 400,000$ million, so costs are about $0.15 \%$ of GDP.

Is it possible to translate these figures into an estimation of the costs of a plan to protect the Netherlands against a 5-m SLR? Technical feasibility of measures aside, one could use the rule of thumb that the volume of material needed to construct a dike relates quadraticly to its height. This extrapolation of the data in Table 1 would indicate that the costs of protection against a 5-m SLR would be about a 30 times current costs and, assuming future GDP will be double current GDP, would be in the range of $2 \%-3 \%$ of GDP $(15 \%-25 \%$ of national investments). This represents a major cost. These costs would exceed benefits by an order of magnitude. These are very much ballpark estimates, and on the high end, neglecting the possibility of cheaper technologies for flood protection, such as preserving and reinforcing existing dunes by pumping sand from the bottom of the North Sea towards the coast.

In the $1950 \mathrm{~s}$, the Delta committee considered an amount of $0.5 \%$ of GDP spent on flood safety to be acceptable (Eijgenraam 2006). The actual costs - relative to GDP - turned out to be lower, partly due to high economic growth. The earlier study of DGW (1986)

Table 1 Costs, benefits and avoided damage of five major flood control works (Stolwijk and Verrips 2000)

\begin{tabular}{|c|c|c|c|}
\hline $\begin{array}{l}\text { Projects to enhance flood safety at foreseen changes } \\
\text { in patterns of river discharges and SLR }\end{array}$ & $\begin{array}{l}\text { Annual } \\
\operatorname{costs}^{\mathrm{a}}(\mathrm{M} €)\end{array}$ & $\begin{array}{l}\text { Annual } \\
\text { benefits }(\mathrm{M} €)\end{array}$ & $\begin{array}{l}\text { Potential } \\
\text { damage (M€) }\end{array}$ \\
\hline Retention basins (excess water storage) (Upper Rhine) & 11 & 118 & \\
\hline Dike heightening and reinforcement (Upper Rhine) & 23 & 118 & \\
\hline Moving river embankments/dikes (widening floodplains) & 16 & 27 & 136 \\
\hline Heightening and reinforcing coastal defences & 369 & 1,739 & 480,018 \\
\hline Enhancing discharge capacity lower Rhine delta & 152 & 908 & 1,090 \\
\hline
\end{tabular}

${ }^{a}$ Annualised capital costs (at $4 \%$ interest rate) and annual maintenance costs 
presented indicative costs associated with three scenarios of flood safety responses to a $5-\mathrm{m}$ SLR occuring over a period of 200 years. The strategy that assumed abandoning the North and South-western part of the Netherlands would cumulatively require expenditures in the order of magnitude of the GDP in 1986, over a period of 200 years. Preserving the territorial integrity would cost about four times more. The latter figures, turned into annualised cost, would compare to $2 \%-3 \%$ of the 1986 GDP.

\section{Analytical framework}

\subsection{The streams model}

The research question is: "What could happen to the Netherlands if, in 2030, the sea level starts to rise and eventually, after 100 years, a sea level of $5 \mathrm{~m}$ above the current level would be reached?". An answer to this question would have at least two elements. First, given the fact that currently about half of the Netherlands is below sea level or on the floodplain of a major river and therefore at risk to floods, an obvious part of the answer would concern the future physical shape of the Netherlands. Second, and more importantly, the answer is about societal responses to such SLR. We decided to describe "societal response" in terms of a framework developed by Kingdon (1984), called the streams model. This model was developed to understand societal-decision making, i.e. to understand when politics decides for certain solutions to certain problems. Kingdon's model is based on the reflection that problems, solutions and politics develop over time and that these streams of problems (as perceived by the public), solutions and politics develop relatively independently from each other. In addition, Kingdon observed that political decisions arise if, and only if, the problem stream, the solution stream and the political stream recombine in a way that is fit for actually taking decisions. Recognising this situation, called a 'window of opportunity', is crucial to understanding of how societal decision-making progresses. Political decision making is not a straightforward process of problem identification, development of alternative solutions, assessment of costs and benefits associated with these solutions, towards the implementation of the solution and subsequently the evaluation of its effectiveness.

Developments in the physical world may very well take place without being noticed by the societal system. But, even if such physical developments are registered, they may not be

Fig. 2 A model to describe societal response to SLR (after Kingdon (1984))

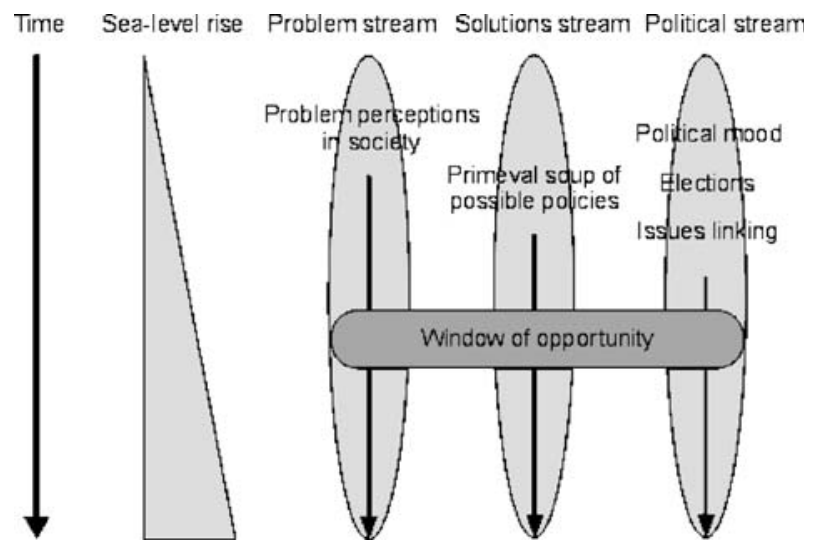


seen as a problem, and/or may not lead to a response from government and other actors in society. In this sense, any 'objective' development in the physical system (but also in the societal system itself for that matter), can be seen as a separate stream that may or may not be connected to the development of problem (perceptions), solutions and political support. Figure 2, an adaptation of Kingdon's figure, depicts this situation.

\subsection{The problem stream}

The problem stream refers to the evolving public opinion about the relevance or urgency of some issue. Currently the 'water awareness' in Dutch society is considered to be relatively low (see De Boer et al. 2003, and the literature cited there). Water issues, especially flooding risks, are considered by the majority of the Dutch population to be under control and there is quite a high level of trust in the existing 'hard infrastructure' such as dikes. People living nearby a river dike do not consider themselves to be significantly more at risk of flooding than those living far away from flood prone areas (see Lijklema 2001). The latest dike reinforcement scheme - after the floods and near floods in the early 1990s along the major rivers - met little resistance. There is less public support for current new approaches such as "giving land back to water" in order to increase discharge capacity of rivers. The aversion against such plans seems very deep seated. Sometimes this aversion is religiously inspired, which can be explained by the fact that the Dutch reformed church has often portrayed the Dutch as the chosen people, the ones that survived the flood of sins. This is not a strong factor in decision processes across the board, but can be regionally relevant. In most other situations, it is simply a disbelief in the necessity for the measures implemented under the new approach to water management and often also a clear issue of diverging interests, with people being unwilling to move farm or house.

Many events and developments may excite public opinion and affect water awareness. Actual floods (or near-floods) are obviously among these signals. Such incidents function as a symbolisation of the problem of climate change, a frame through which these natural events are being viewed. For instance, the Hurricane Katrina disaster in New Orleans, widely covered in the media, was associated with climate change fed the publicly felt urgency to address flood safety. However, the further away and the longer ago a flood disaster, the lower the publicly felt urgency. In this respect, one may also note that awareness of specific risks among people depends on, among other factors, individual experience with the hazard (Zwick and Renn 2002; de Boer 2006).

\subsection{The solutions stream}

The solutions stream consists of proposals for strategies, technical measures, and legislation put forward in speeches and (scientific) publications by the policy making community and adjacent domains. The ideas about certain measures that are generated near or in this milieu may circulate for years without anything being done with them. The so called policy brokers must massage the other members of the policy community (mainly bureaucrats and experts), that is: get them to believe that 'their solution is the best one'. Policy brokers are people who believe in certain solutions and invest a large amount of time and energy in their 'pet solutions'. This process, according to Kingdon, is mainly one of argumentation and convincing. In the end, ideas, in order to be taken seriously, must meet three criteria according to Kingdon. These are: (1) technical feasibility, (2) fit to the national political mood, and (3) fit to dominant values within society. 
Dutch water managers have been portrayed as 'water magicians', that can practically achieve any goal (Goverde 1987). In the 1930s, and to a lesser extent also in the 1960s and 1970 s, water projects were completed that generated considerable national pride (e.g. the closure of the Zuiderzee dam, the 'delta works' in Zeeland and Zuid-Holland). It was exactly this image of technically able experts and the feeling that water managers were serving important national goals (safety from flooding, and through the creation of polders also food production and housing) that gave them great powers in certain parts of the country. This was the case in the IJsselmeer-polders created by 1968 , where ordinary government layers were absent until the 1980s. Water managers throughout the country had serious conflicts with environmental groups that sought to protect the traditional landscape from canalizing and rationalizing the water system by both the national and local water authorities. These debates were often held in the context of the land use planning system, which opened up for citizen participation in the 1960s and 1970s. These conflicts did have important impacts in the policy community. First, nature became a far more important concern for water managers. Second, the dominance of the land use planning system over the water managers was established. As the land use planning system was not very much 'water minded', this second development may have played a certain role in the large amounts of development that have taken place since without much regard to the interest of proper water management. This situation lasted until the 1990s when the problems with the River Rhine and Meuse sounded the alarm bell and water became more important for land use planners. This led in the end to the 'Room for Water' policy described earlier.

In the Netherlands, within bodies engaged in discussion of water management, there is awareness that climate change may have potential consequences for SLR and flood risks. Strategic planning in the area of water management and flood safety is based on the assumption of up to $1 \mathrm{~m}$ SLR from climate change (and soil subsidence) in the present century (WB21, Tielrooij 2000). Numerous studies of flood safety have been made in the last decades in The Netherlands. For instance, the National Institute for Public Health and the Environment recently analysed the Dutch flood security policy (Ten Brinke and Bannink 2004) from various disciplinary angles and with respect to different types of risk (see also Van Asselt 2001; Middelkoop et al. 2001; Bouwer and Vellinga 2007; Vrijling 2004).

\subsection{The political stream}

The political stream consists of the 'national mood', changes in government or bureaucracy, and the acts of interest groups. Changes of government, certainly if they bring a new 'meta agenda' (e.g. safety or health care), imply opportunities for the presentation of either problems or solutions to the government. In particular, this may include already developed solutions that can be adjusted to fit into the 'meta agenda' of the new government. Support in the political stream, according to Kingdon, arises in a different fashion than support for solutions in the 'solutions stream'. The difference is that support in the political stream arises mainly as a result of exchanges and compromises and to a lesser extent as a consequence of argumentation. The most important actors in this respect are elected representatives and members of government. Interest groups, according to Kingdon, are far less influential in bringing issues to the attention of politicians than other politicians. Senior government officials, such as the Prime Minister, have an especially important impact on the degree to which issues are let in to the formal agenda.

The historical perception of water in the Netherlands is that of an enemy ('the waterwolf') against which protection through cooperation and technical means is necessary. Certainly in cases of floods, such old images return rather easily. It is important to 
acknowledge however that the perception of water for the Dutch has changed considerably of late. In the 1930s, we saw the arrival of interest groups for water recreation that seek to protect the open space that large water masses offer to the Dutch. The political support for measures that reduce this open space or infringe upon the landscape tend to be limited, although shoreline development is popular amongst house buyers. The solution 'Room for Water' can benefit from this. On the other hand, the Dutch are clearly a risk averse society in the sense that its population and politicians consider disasters unacceptable (Huysmans and Steenbekkers 2002). Certainly when (near) disasters occur, this aversion is clearly visible. The political dangers associated with such disasters are enormous and may outweigh the resistance that exists against strong measures (i.e. a rigid defence).

\subsection{Policy windows}

Kingdon distinguished between the formal agenda (those issues that the government defines as a problem) and the decision agenda that consists of the issues upon which decisions are taken and policy will be made. Kingdon speaks of an 'open policy window' when the political system prepares itself to actually couple solutions to certain problems. Whether or not there is a policy window depends mainly on the political and the problem streams. Politicians either see a certain problem as something unavoidable or politicians themselves place an issue at the top of the political agenda. In both cases, politicians will start looking for solutions and if these are found, the solutions can become coupled to a certain problem. Kingdon suggests that windows need to be used promptly, before they close quickly. Windows close in the following situations: (1) politicians are of the opinion that they have acted upon the problem (even if the policies they have adopted are purely symbolical in nature), (2) if agreement on the solution is not reached quickly, (3) if the event that indicated the need for policy fades from memory, (4) if another political change occurs, (5) if those in the solutions stream are in disagreement about a preferred solution.

An important issue for many policy analysts is whether the process of opening up and closure of policy windows is something that can be managed or controlled. Kingdon stated that: 'Sadly for strategists trying to manipulate the process, the world is not quite that simple' (1984: 179). In fact, even the question whether a window is open or not is difficult to answer. On the other hand, Kingdon does suggest a few lessons for practice: (1) a window should not be allowed to attract too many solutions, because then the issue becomes unmanageable, (2) windows are often generated by 'policy entrepreneurs'. Such people are taken seriously by others because they either have expertise, represent an important group of backers, or occupy an important office, (3) certain windows are cyclical in the sense that they are connected to processes that are predictable, such as the government budget cycle.

\section{Methodology}

In developing a scenario, one can use various possible methods. Some methods rely on computer models that generate future trends, others are based on discussions between experts and stakeholders, and sometimes these two elements are combined. In our case, we used the second approach. The methodology we used boils down to a set of semi-structured interviews and the organisation of an expert workshop. About half of the workshop participants were among the experts that were interviewed. 
From the literature and from discussions among the partners within the ATLANTIS project we identified a series of issues, which we used to structure the interviews and to support the development of a scenario. These issues were, in summary:

- Options: what response options or possible forms of adaptation are there? (e.g. migration and abandoning land, heightening dikes).

- Actors: what people would initiate processes of response and what would these responses be? (e.g. political processes such as coalition formation among actors that share interests).

- Processes: what societal processes would be seminal to eventual developments?

- Analogues: are there historical developments that would be informative to considering possible responses to the assumed SLR?

- Trends: what current and expected trends in thinking and acting might be important to eventual societal responses?

In order to further identify and specify what is actually considered important in society and which processes or trends are thought to determine possible future responses to an accelerated SLR, we interviewed professionals in domains assumed to be directly affected by SLR or to be of influence in societal responses to extreme SLR. A number of potential interviewees were identified and approached. The interviewees were briefed by sending them a checklist of issues that were thought to be relevant by us (see above) and they were invited to consider those issues that were familiar to them. Space was left, however, to discuss items deemed relevant to the interviewees. During the interviews, sets of questions were discussed one by one in an open way. This created a certain structure, whilst leaving enough space for the development of creative thought. Fifteen in-depth interviews were held over a time-span of 6 months. About a third of the interviewees were social scientists (mainly from academia), about a third were civil servants engaged in strategy and policy development related to flood risks. The others included a former politician, water management engineers, and representatives of major industries.

Eight of the interviewees together with four other scientists (see Table 2) participated in a 1-day workshop that was intended to elicit ideas about the future. All participants were experienced in their field of expertise and demonstrated ability for strategic thinking.

Table 2 Workshop participants and their discipline

Civil servant Ministry of Transport and Water management. Strategic planning

Civil engineering company; senior consultant to water management development

Former politician and secretary of state of the Ministry of Transport

and Public Works. Geography background

Senior civil engineer of major dike engineering firm

Professor of environmental economics. Climate change policy analysis

Environmental social scientist; stakeholder analysis (chair)

Social psychologist; public reactions to environmental risk

Professor of political science; stakeholder analysis

Economist of Dutch Bureau for economic policy analysis. Long-range economic scenario construction

Landscape architect of a major consulting firm for land use planning

Civil servant of the Rotterdam Harbour Authority. Strategic planning

Environmental sciences; climate change risk analysis 
During the workshops, we asked them not to speak on behalf of their organisations, but rather to let their professional judgement lead them.

The structure of the workshop was derived from the procedure of a "policy exercise" (see Toth and Hizsnyik this issue), with the difference that participants were not asked to play roles in a policy game. Instead, the participants were asked just to contemplate - interactively - possible events in the Netherlands during a 100-year SLR of $5 \mathrm{~m}$. Since we expect that the socio-economic situation in the future will influence responses to the SLR, we asked participants to consider societal response for two different socio-economic futures, derived from a recent study of the future (period 2000-2030) economy of the Netherlands (Lejour 2003). One future is a world with ongoing globalisation, emphasis on economic efficiency, and limited role of the government in the private sector. Such a future would result in high economic growth $(2.5 \%$ annually) and a relatively unequal income distribution. The other future, under a trend away from further globalisation and striving for economic efficiency through market mechanisms, would imply lower economic growth $(0.6 \%$ annually) and a relatively equal income distribution. Such difference in the rates of economic growths imply that in about 50 years the Gross Domestic Product (GDP) would differ by a factor 2 .

The workshop agenda held four items:

- A briefing about the project, the SLR scenario, the analytical framework, current long term socio-economic scenarios, and the goals of the workshop

- A discussion of possible events and processes that might occur in the period 20302050, i.e. the beginning of the SLR

- A similar discussion about possible processes and events in a second period 20502070

- A similar discussion about the final period 2070-2130

The three periods were selected against the background of our assumption that in this case of a fast SLR the uncertainty in society about the rate and eventual height of SLR would gradually decrease, i.e. initially signals of SLR would not be recognised by society, whereas later it would be impossible to deny. We distinguish three periods in this century of SLR. Initially - we arbitrarily choose 2030-2050 - uncertainty and incredulity is dominant in society, later - say 2050-2070 - when the sea level will have risen by say $2 \mathrm{~m}$, SLR cannot be denied, but there will still be uncertainty about its eventual magnitude. In the last period the SLR is assumed to be an accepted fact.

In sum, we structured the workshop discussions along two main lines: the model of streams of problems, solutions and politics and a timetable with three periods.

\section{Responses to future accelerated SLR: Problems, solutions and politics}

Below we summarize the findings of our interviews and, in particular, the discussions at the workshop (February 2004). In so-doing we followed the logic of the Kingdon model, describing streams of problems, of solutions, and of politics through time. We emphasise that these descriptions are our synthesis and interpretations of interviews and discussions at the workshop (Olsthoorn et al. 2005), rather than their verbatim account.

\subsection{Problems}

In what ways does sea-level rise affect society, and how do societal problems arise and evolve? Perception is the common element in the answers to these two questions. Whether 
and how SLR affects society and prompts a societal problem is a question of sociological, psychological, economic, and political processes. Perceptions, for instance the meaning attached to reports about events attributed to SLR, would be the first step in such a process. Early signs of rising flood hazard are likely to be the first step on the way towards the realization that there is a societal problem. Many factors and circumstances do influence the problem perception formation process and its outcomes. The eventual perceived magnitude of a societal problem, may well be out of proportion (social magnification or attenuation), as analysts of such processes have observed (Kasperson et al. 1987).

Our respondents suggest that the very first signs of a probable accelerated SLR will likely stem from individual scientists, who report their scientific findings. Later on an international organisation, such as the Intergovernmental Panel on Climate Change, could be the platform from which these signs may reach a wider public. However, whether these signs are picked up, that is the awareness of accelerated SLR will increase, depends on people's earlier experience, among other reasons. The respondents suggested for instance, that the personal experience of swimming might enhance somebody's awareness about the hazards of floods. If true, groups of people that are not able to swim are expected to be less receptive to warnings of flood risk. In contemporary Dutch society immigrants are often are unable to swim, unlike the majority of the Dutch population. As was noted at the workshop, this circumstance and possibly other idiosyncratic cultural characteristics of immigrants are relevant to developments in "water awareness" of the Dutch population and the initial value attached to the first signals of accelerated SLR.

Later on people themselves might notice SLR during and after extreme weather events. SLR, for instance, will cause the occurrence of near floods and nuisance from excess water after periods with high precipitation to increase. 'Focusing events' such as the Hurricane Katrina disaster in New Orleans, are also likely to enhance local awareness about SLR and its associated risks. Obviously, if a major disaster strikes, public belief in SLR and the societal urgency of the problem would increase overnight and radically. Another mechanism through which the social perception of the problem will increase would be the advancement of the science on the collapse of the WAIS and the dissemination of its results, i.e. full scientific consensus communicated to the mass media.

The problem, however, is seen as having multiple dimensions, and not just as a flood hazard issue. One dimension that will come to the fore is that of economics. The workshop participants suggested that the areas at greatest risk would become less attractive to live and to invest in. House prices may fall and economic development likewise will be hampered or even reversed. Flood hazard develops into an economic hazard, initially in areas most at risk where investors would leave the area, while later on people would experience that the whole of the Dutch economy would be at risk, with the exception that the water management industry and engineering would flourish. Compensation for property and income loss might be sought for from the local and national government and perhaps from the European Union (EU).

Workshop participants indicated that a future SLR could divide the Netherlands economically and politically into three parts. The first part would be constituted by the subsea level parts in the west and north of the country, which are areas that are economically less prosperous and have relatively low population densities. The respondents suggested that the debates about management options would centre around the costs of extra flood defences. This is because the costs might greatly exceed the benefits, and that population would have to migrate. The second part would be the economic "core area" in the west, in which $80 \%$ of the national assets are located. This core area is essentially constituted by the Amsterdam-The Hague-Rotterdam metropolitan conglomeration, including the international hub Schiphol Amsterdam airport and the harbour of Rotterdam. The third part would be the eastern and 
southern parts, which will not face immediate dangers of flooding (except for the floodplains of the big rivers). Their inhabitants may be less willing to share costs at the national level for defence of the other regions. Also they may resist mass immigration to their regions. It was noted that people living in these areas tend to be wealthier than people in low-lying areas. SLR might therefore evolve into a political problem of regional conflict.

\subsection{Solutions}

As mentioned above, an earlier study was made of policy options for flood safety management in the Netherlands in response to a $5 \mathrm{~m}$ SLR occurring over 200 years (Rijkswaterstaat-DGW 1986) - as opposed to the 100 year timescale or our study. This study distinguished three options to cope with such SLR. The first, most radical, and expensive approach was to build a complete new dike around the Netherlands and facilities to deal with (excess) river water. The second option was to reinforce existing flood-defence structures, while the third option was to leave the South-Western and Northern parts of the Netherlands being of relatively lower economic importance - while protecting the economically important area of Amsterdam, Rotterdam and the Hague (more or less comprising dike ring areas 14, 44 and 45 as indicated in Fig. 1). This study suggests that, engineering-wise, the Netherlands could cope with a 5-m seal level rise. Our interviews with civil engineers engaged in flood protection confirmed that the constraints on the management of flood protection were not of a technical, engineering, or economic nature, but rather that responses to SLR are constrained by social and political conditions. With respect to engineering options, participants noted that there would possibly be other ways to address the risk of SLR. For instance, one participant came with the idea to connect the Qattara depression (a basin of about $26,000 \mathrm{~km}^{2}$ in the Libyan Desert, with a lowest point of about $134 \mathrm{~m}$ (440 ft) below sea level) with the Mediterranean Sea, which would lead to a reduction in SLR ${ }^{2}$. Another suggestion was to raise the height of motorways, thereby dividing the areas-at-risk into smaller compartments and reducing overall risk. When the abandonment of areas-at-risk becomes an acceptable option, it becomes necessary to devise ways to channel migration away from these areas. Mechanisms to financially compensate people, industry and farmers would need to be designed and would be part of the solution stream. Part of more long-term approaches would be educational programmes aimed at preparing a current young generation for a future with elevated sea levels. Education at schools was also mentioned as a means to enhance public awareness about SLR and its consequences.

The workshop participants considered several contextual issues that could be relevant from the perspective of the solution stream. A first issue was the role of the EU. Accelerated SLR might prompt a reaction at the European level and the EU might introduce legislation to channel adaptation, for instance a mechanism for financial assistance to implement adaptation measures. As was said at the workshop, the Netherlands could claim for financial support since, in the middle of the century, the Netherlands will have been a net contributor to the EU budget; and will have transferred substantial sums of money to other EU member states., It was, however, also noted that the idiosyncrasies of the Dutch situation, e.g. related to the existence of polders and the firmly established institutions to cope with flood risks, might not match the "average" European problems and EU solutions. Therefore, such EU policies may not necessarily be beneficial within the scope of possible adaptation strategies in The Netherlands.

\footnotetext{
${ }^{2}$ It should be noted that this reduction would be very small.
} 
A second issue mentioned at the workshop and during interviews is "migration". The participants suggested that the Dutch population could become less migration averse, as the result of many people having visited foreign countries, and speaking foreign languages. Internet and other electronic networks provide new means of communication, which may at least partly be a substitute for face-to-face contacts between friends and family members. Today a substantial proportion - about $15 \%$ - of the Dutch population is of foreign origin (CBS 2003). These facts are interpreted by the respondents as indications that migration could become a smaller step in people's minds than it is today. Migration, as a response to signals of enhanced risks, might therefore start relatively spontaneously, through immigrants returning to their home country, retired people moving to the European sunbelt, and small and medium sized businesses moving to safer parts of the Netherlands. It was also pointed out at the workshop that migration away from the congested urban areas in the Western part of the Netherlands towards less densely populated areas in the eastern (and higher) parts of the Netherlands is already ongoing. Such developments might be reinforced and evolve into larger scale spontaneous migration without additional migration policy by local and national government. The existence of job opportunities elsewhere is expected to be a decisive influence on migration (or flight) from areas at risk. However, if disaster strikes and large groups of people are forced to move elsewhere at relatively short notice, the SLR problem may encompass issues such as the existence of refugee camps. If the return of people is not possible, there will be a range of problems related to housing and jobs.

The solutions or possible strategies discussed above relate to problems as seen from the public or government point of view. Private actors, e.g. private companies, may have their particular concerns, or will see benefits in the problems. Concerns will prompt company managers, together with politicians, to take timely initiatives and protect the areas of major industrial importance against flood hazards. Crucial in this process is the opinion formation among top managers about the likelihood of SLR and its hazards and the relative costs and benefits of protection versus retreat. A major risk would be that companies (i.e. their top managers) decide to relocate away from the western and northern parts of the country, such as the "core area" of Rotterdam, Amsterdam, and The Hague which area encompasses about $80 \%$ of the country's economic assets.

On the other hand some industries would strongly support strategies to preserve land, since this could generate business opportunities. In particular, the Dutch coastal engineering industry could benefit from an increasing market for flood protection schemes, both in the Netherlands and across the world. Stakeholders from other sectors, in particular land-based activities than cannot be moved to safe areas, would also be expected to support protection strategies. A major loser would be agriculture. This sector will also suffer from salt-water intrusion due to increasing hydrostatic differences between sea level and in-polder ground water levels.

At the workshop, a fourth option, to abandon the entire area at risk, was also considered. This possibility was eventually - at the end of the workshop - considered to be the most likely according to the workshop participants, given the assumed future context of rapid SLR, and the slowness of the policy response, as argued above.

\subsection{Politics}

Flood safety levels and assets-at-risk are unevenly distributed over the country (see Fig. 1 and its explanation in Section 2). Under SLR, the differences in risks would increase and may lead to political conflict since resources for flood safety policies are likely to be limited. Eventually, when the flood security issue has risen into the top of the political 
agenda, the political landscape may be shaped along lines of flood security. Political parties could be created that would defend the interests of those living on high ground against those living in threatened areas (highlanders versus lowlanders). The Dutch election system may facilitate such a development, as it is based on proportional representation without election thresholds, and therefore allows for relatively easy entry to Parliament for new parties. Several instances are known of rapidly emerging parties, with some new parties even taking one sixth of the vote and Parliamentary seats.

With respect to how and when political decisions are made (the opening of a window of opportunity), interviewees and workshop participants strongly held the opinion that major political decisions would only being made if politicians can frame them as win-win options. As noted in the workshop, for politicians it is important that they appear successful to the public, especially during election times. So governments and politicians (in office) will continue to radiate trust and adequacy in flood protection structures. The central government, and to a greater extent local governments, will not consider the abandonment of territory and forced migration of people lightly. Therefore, politicians are not expected to relate the message that flood protection has become inadequate. Such a message would have to come from the chance event of a flood disaster. It was noted that for local politicians - faced with local problems - the inclination to take on the issue would develop more quickly than for politicians at a higher governmental level. This could evolve into conflicts between local and national governments and also into conflicts between national and European level government.

The respondents suggest that politicians will be more responsive to public opinion than to warnings from scientists. Rather than taking the lead in reaction to announced threats of SLR, politicians, according to workshop participants, will only consider SLR as a problem of political importance once floods or near flooding occurs. Other actors (e.g. individuals, firms, investors) are less restricted in their actions and may respond faster to changing circumstances. The workshop participants stressed that the initiators of new developments are usually "non-governmental" actors. Actors peripheral to mainstream governance often initiate new developments and foreshadow a government's decision making.

In sum, the message about the role of politics in adapting to the assumed SLR is that initiatives to embark on actions can only be expected after signals of the SLR have been sufficiently picked up by the public. Since politicians will not send out such signals, the scenario is that decisions will only be made after events such as flood disasters.

\subsection{And eventually, in 2130?}

At the end of the workshop, there was a commonly held opinion that, if the sea level would rise by $5 \mathrm{~m}$ in 100 years from 2030 onwards, in 2130 large parts of the Netherlands would be abandoned. Not for technological reasons, but because of social processes that would inhibit decision making aimed at preserving territorial integrity. This result would not depend on the nature of socio-economic development as considered in the two socio-economic futures presented at the workshop briefing (See Section 4).

\section{Discussion and conclusion}

The central question of the present study was: what could happen to the Netherlands and Dutch society during a century of SLR of, eventually, $5 \mathrm{~ms}$ ? Note that we did not want to assess the probability of a collapse of the WAIS and a consequent $5 \mathrm{~m} \mathrm{SLR}$, or a particular 
policy outcome. Rather, we focused on identifying characteristics of and processes within Dutch society that can be considered as constitutive to possible responses of Dutch society to such SLR. We identified these characteristics and processes by interviewing experts and through a scenario-building workshop. To structure the analysis we used Kingdon's model (1984) of societal decision making, which sees decision making as flows of problems, solutions (policies being discussed) and politics, which when occasionally aligned may result in a decision.

Our interviews with experts in flood defence indicate that technically (i.e. without any considering financial or organisational constraints) it would be feasible to largely maintain the geographical integrity of the Netherlands under a 5-m SLR. In their opinion, however, and also in the opinion of experts in other fields, social and political processes make it unlikely that decisions to carry out such a policy can be made in time. The rate of SLR may be faster than the rate of social processes that precede and enable such decisions. For example, SLR can bring about conflicts of interests among those who are exposed to high risks and those who are not and are not willing to pay for risk control elsewhere. Windows of opportunity to make major decisions on enhancing flood safety that would resolve or alleviate such conflicts are generally only possible in a brief period after a disaster or other chance events. The history of investments in water related infrastructure in The Netherlands very clearly illustrates this phenomenon (Van de Ven 1996). Alongside decision-making by governments, processes that are beyond the control of governments, such as migration of individuals and firms away from at-risk areas, have a profound influence on the eventual "state" of the Netherlands.

In current flood safety policies, the environment is an important aspect. One of the justifications for selecting the "Room for Water" strategy (see Section 2) is that creating room for water simultaneously creates nature conservation areas (Tielrooij 2000). An earlier study (Rijkswaterstaat-DGW 1986) of a 5-m SLR in 200 years, discussed the possible effects of SLR on ecology and nature conservation extensively ${ }^{3}$. So it is striking that our interviews and workshop did not bring forward environmental issues-i.e. conservation of natural areas as a very important topic among the other issues. A possible explanation for this would be that nature conservation would be a minor issue in comparison to a serious threat to the whole Dutch society. Another explanation is that, in general, the outcomes of workshops about the future tend to reflect current ideas rather than future thought.

Eventually, after a 5-m SLR in 100 years, the geography of the Netherlands could be quite different from its current shape. According to the outcome of the workshop, under a very rapid 5-m SLR of $5 \mathrm{~m}$, the territorial integrity of the current country of the Netherlands will likely be lost and many people will live in other places than they would without such SLR.

Our SLR scenario is useful in two ways. First, the community of coastal zone and hazard management may come to reflect on the implications of $5 \mathrm{~m}$ SLR in their area and take account of such future in policy development; worst-case scenarios may become selfdefeating. Secondly, the results from this study can be used in climate change policy analysis, i.e. greenhouse gas emissions abatement. In that context, it is assumed that there are possibilities to avoid extreme SLR and, consequently, it makes sense to assess and

\footnotetext{
${ }^{3}$ This report was published at a time of an extensive public discussion about the permanent closure of the Oosterscheldt estuary, resulting in the loss of ecologically valuable wetlands. This lead to the decision to build the moveable dam mentioned in section 2 .
} 
exploit the possibilities of greenhouse gas emission abatement vis-à-vis avoided risks associated with climate change.

An important conclusion from our results is that there are grounds to further investigate the physics of the WAIS, and other potential sources of important climate events such as the melting of the Greenland Ice Sheet. Such investigations are needed to make better judgments on how such events may evolve over time and consequently to better justify possible policies that would reduce the risks associated with a WAIS collapse. In addition, given the expectation that the rate of social processes, such as social learning would limit adaptation, the study of the latter is at least equally useful.

Acknowledgements The authors are indebted to the interviewees and the participants of the Dutch Atlantis workshop on 12 February 2004, and to colleagues in the Atlantis project. Comments from three anonymous referees helped to improve this article. The project was financially supported by the European Commission under the project number EVK-CT-2002-000138. All interpretation, opinions and possible errors are our responsibility.

Open Access This article is distributed under the terms of the Creative Commons Attribution Noncommercial License which permits any noncommercial use, distribution, and reproduction in any medium, provided the original author(s) and source are credited.

\section{References}

Beck U (1992) Risk society: towards a new modernity. SAGE, London

Birkland ThA (1997) After disaster: agenda setting, public policy, and focusing events. Georgetown University Press, Washington, DC

Bouwer LM, Vellinga P (2007) On the flood risk in The Netherlands. In: Begum S, Stive MJF, Hall JW (eds) Flood risk management in Europe: Innovation in policy and practice. Springer, Berlin (pp 469-484)

Bressers JTA, Huitema D, Kuks SMM (1995) Policy networks in Dutch water policy. In: Bressers JThA, O’Toole LJ, Richardson JJ (eds) Networks for water policy. A comparative perspective. Frank Cass, London, pp 24-51

Brouwer R, van Ek R (2004) Integrated ecological, economic and social impact assessment of alternative flood protection measures in the Netherlands. Ecol Econ 50(1-2):1-21

CBS (2003) Bevolkingstrends. Statistcs Netherlands (CBS), Statistisch kwartaalblad over de demografie van Nederland 51(2), Heerlen/Voorburg

De Boer J (2006) A psychological view on industrial transformation. In: Olsthoorn X, Wieczorek AJ (eds) Understanding industrial transformation. Views from different disciplines. Kluwer, Dordrecht, pp 27-46

De Boer J, Huitema D, Goosen H (2003) Bewust werken aan waterbewustzijn. Studie naar de rol en relevantie van het begrip waterbewustzijn voor het waterbeleid (Conscious work on water consciousness), Report E-03/09, Institute for Environmental Studies, Vrije Universiteit Amsterdam (in Dutch)

Dryzek J (1987) Ecological rationality. Environment and political economy. Blackwell, Oxford

Eijgenraam CJJ (2006) Optimal safety standards for dike-ring areas. Discussion Paper 62, Netherlands Bureau for Economic Policy Analysis, The Hague

Goverde HJM (1987) Macht over de Markerruimte. Geografisch en Planologisch Instituut KUN, Nijmegen

Guillerminet M-L, Tol RSJ (this issue) Decision making under catastrophic risk and learning: the case of the possible collapse of the West Antarctic Ice Sheet. Clim Change

Gunderson LH, Holling CS (eds) (2002) In: Panarchy. Understanding transformations in human and natural systems. Island, Washington DC

Hansen JE (2005) A slippery slope: how much global warming constitutes "dangerous anthropogenic interference"? Clim Change 68:269-279

Hartman E (1991) Niemand houdt mij tegen (Nobody will stop me). Lemniscaat, Rotterdam (in Dutch)

Huitema D (2002) Nurturing nature: how to make a lake and maintain it. The IJsselmeer case as an example of some modern dilemma's and tendencies in Dutch water management. University of Twente, CSTM, Enschede 
Huitema D, Kuks SMM (2004) Harboring water in a crowded European delta. In: Bressers JTA, Kuks SMM (eds) Integrated governance and water basin management. Conditions for regime change towards sustainability. Kluwer, Dordrecht, pp 61-100

Huysmans F, Steenbekkers A (2002) Kijken naar gevaren. Over maatschappelijke percepties van externe veiligheid. (Looking at dangers. On social perceptions of industrial safety). Social and Cultural Planning Office of the Netherlands (SCP), The Hague (in Dutch)

Kaijser A (2002) System building from below, institutional change in Dutch water control systems. Technol Cult 43:521-548

Kasperson RE, Renn O, Slovic P, Brown HS, Emel J, Goble R, Kasperson JX, Ratick S (1987) The social amplification of risk: A conceptual framework. Risk Analysis 8:177-187

Kasperson RE, Bohn MT, Goble R (this issue) Assessing the risks of a future rapid large sea level rise: a review. Clim Change

Kingdon JW (1984) Agendas, alternatives and public policies. HarpinCollins, New York

Kuks SMM (2004) Water governance and institutional change. Twente University Press, Enschede

Lejour A (2003) Quantifying four scenarios for Europe. Netherlands Bureau for Economic Policy Analysis (CPB), The Hague

Lijklema S (2001) Water beheren en communiceren: een studie naar het publieke draagvlak voor het waterbeheer in Nederland. PhD Thesis, Wageningen University

Lythe M, Vaughan DG, BEDMAP consortium (2001) BEDMAP: a new ice thickness and subglacial topographic model of Antarctica. J Geophys Res 106(B6):11335-11352

Middelkoop H, Daamen K, Gellens D, Grabs W, Kwadijk JCJ, Lang H, Parmet BWAH, Schädler B, Schulla J, Wilke K (2001) Impact of climate change on hydrological regimes and water resources management in the Rhine Basin. Clim Change 49:105-128

Nicholls RJ, Tol RSJ, Vafeidis N (this issue) Global estimates of the impact of a collapse of the West Antarctic Ice Sheet. Clim Change

Olsthoorn AA, van der Werff PE, Bouwer LM, Huitema D (2005) Dutch Atlantis: the Netherlands if the sea level rises with $5 \mathrm{~m}$ in the period 2030-2130. Institute for Environmental Studies Vrije Universiteit, Working paper W 05/01, Amsterdam

Oppenheimer M, Alley RB (2005) Ice sheets, global warming, and article 2 of the UNFCC. Clim Change 68:257-267

Rijkswaterstaat DGW (1986) Zeespiegelrijzing (Sea level rise), Rijkswaterstaat Dienst Getijdewateren. Mimeography (in Dutch)

Rijkswaterstaat DWW (2003) De veiligheid van de primaire waterkeringen in Nederland-Resultaten van de eerste toetsronde van 1996-2001. (The safety of primary flood defences-results of the first survey 19962001). Directorate-General of Public Works and Water, Road and Hydraulic Engineering Division, Delft (in Dutch)

Rijkswaterstaat DWW (2005) Flood risks and safety in the Netherlands (Floris) Full report. DirectorateGeneral of Public Works and Water Management, Road and Hydraulic Engineering Division, DWW2006-014, Delft

Rijkswaterstaat DWW (2006) Primaire waterkeringen getoetst: Landelijke Rapportage Toetsing 2006. Directorate-General of Public Works and Water Management, Road and Hydraulic Engineering Division, Delft (in Dutch)

Schama S (1987) Embarrassment of riches: an interpretation of Dutch culture in the golden age. Collins, London

Stolwijk H, Verrips A (2000) Ruimte voor water. Kosten en baten van zes projecten en enige alternatieven. Working document No 130, Netherlands Bureau for Economic Policy Analysis (CPB), Den Haag (in Dutch)

TAW (2000) From probability of exceedance to probability of flooding: towards a new safety approach. Technical Advisory Committee on Flood Defences, Delft

Ten Brinke WBM, Bannink BA (2004) Dutch dikes and risk hikes. A thematic policy evaluation of risks of flooding in the Netherlands. Report 5007990002, RIVM-Netherlands Environmental Assessment Agency (MNP), Bilthoven

Tielrooij F (ed) (2000) In: Waterbeleid voor de 21e eeuw (Water policy for the 21st century). Commissie Waterbeheer 21e Eeuw, The Hague (in Dutch)

Tol RSJ, Langen A (2000) A concise history of Dutch river floods. Clim Change 46:357-369

Toth FL, Hizsnyik E (this issue) Managing the inconceivable: participatory assessments of impacts and response to extreme climate change. Clim Change

Van Asselt MBA (2001) Development of flood management strategies for the Rine and Meuse basins in the context of integrated river management. Netherlands Centre for River Studies publication 16-2001 
Van Dantzig D (1956) Economic decision problems for flood prevention. Econometrica 24:276-287 Van de Ven GP (ed) (1996) In: Man-made lowlands. Matrijs, Utrecht

van der Grijp NM, Olsthoorn AA, Tol RSJ, van der Werff PE (2006) Flood risk institutions and climate change in the Netherlands. In: Ruth M (ed) Smart growth and climate change. Edward Elgar, Aldershot, pp 243-268

Vrijling H (2004) Vroegtijdige detectie van milieurisico's-transitie "Verhoogde dijken". In: van Asselt M (ed) Nieuwe risico's in het vizier? RMNO \& Lemma, The Hague, pp 62-79

Wissink B, Bouma J (red.) (2002) Perspectieven op milieurisico's. Wetenschappelijke Raad voor het Regeringsbeleid (WRR), W 128, Den Haag

Zwick MM, Renn O (eds) (2002) Perception and evaluation of risk. Findings of the Baden-Wuerttember Risk Survey 2001. Joint report of the Akademie fur Technikfolgenabschatzung and the University of Stuttgart, no. 203 